\title{
Ethics of Care and Responsibility: Normative Fragments
}

\author{
Per Nortvedt
}

Published online: 29 January 2011

(C) The Author(s) 2011. This article is published with open access at Springerlink.com

In May 2009 Center for Medical Ethics, University of Olso, organized a workshop financed by the Norwegian Research Council on the title: Care and NormativityPhilosophical and empirical challenges. The workshop gathered scholars who worked on philosophical as well as empirical questions related to the perspective of care ethics. The workshop was particularly proud to host Michael Slote and Joan Tronto, both from the USA. Michael Slote spoke on his theory of an empathy-based care ethics and Joan Tronto on the role of partiality and justice in a democratic society.

Most of the other papers at the workshop is presented in this current issue of Health Care Analysis. The papers range from philosophical and empirical analysis of partiality and justice in health care (the papers by Holm, Nordhaug and Skirbekk) to the role of care in nursing and medicine and narrativ ethics (Martinsen and Paulsen). Empirical analysis of mature care is combined with a thorough philosophical discussion about the relevance of this concept to current care ethics (Hem and Pettersen) and finally postmodern and feminist perspectives are argued to have particular significance to current ethics of care (Skærbaek). I am very glad to be able to participate in this work of focusing on the particular normative aspects of an Ethics of Care, and that the Journal of Health Care Analysis has been so kind to give priority to this topic in a special issue.

Ever since Carol Gilligan's work on care back in the late seventhies, an ethics of care has been claimed to be mainly descriptive and to have less importance as an action guiding and normative ethical theory. When it comes to the central issues of normative theory, such as to solve questions about justice, to justify and argue for particular moral actions, solving competing moral claims etc. many have taken an ethics of care not to be particularly relevant. Many have argued that the theory

P. Nortvedt ( $\square)$

Center for Medical Ethics, Institute of Health and Society,

The Medical Faculty, University of Oslo, Oslo, Norway

e-mail: p.nortvedt@medisin.uio.no 
mainly explain and allows for supererrogatory actions, actions determining what might be morally praiseworthy, but not right and obligatory.

I certainly do not believe this to be right, but I do think that theoretical and empirical research within the field of care ethics still have a lot to accomplish in developing the perspective of care in a more substantial normative direction. I certainly both think and hope that the contributions in this special volume of the journal will accomplish in this task.

Open Access This article is distributed under the terms of the Creative Commons Attribution Noncommercial License which permits any noncommercial use, distribution, and reproduction in any medium, provided the original author(s) and source are credited. 